\title{
Monitoring of Energy Efficiency of District Heating System Facilities: Methodology for Determining the Energy Baseline
}

\author{
${ }^{1}$ Davydenko L.V., ${ }^{1}$ Davydenko N.V., ${ }^{1}$ Davydenko V.A., ${ }^{2}$ Sprake D. \\ ${ }^{1}$ Lutsk National Technical University, \\ Lutsk, Ukraine \\ ${ }^{2}$ Wrexham Glyndwr University, \\ Mold Road, Wrexham, UK
}

\begin{abstract}
Determining the energy consumption level is one of the stages of energy efficiency monitoring facilities. The aim of the article is to adapt the energy baseline to the operating conditions of the facility in accordance with the ISO 50000 Standards requirements. The methodology for determining the energy baseline was proposed to achieve the goal. The three-stage procedure for forming a set of relevant variables of the energy baseline, which allows taking into account the significance of variables, the possibility of their measurement, controllability and control, and the procedure for constructing a multifactorial model of the optimal structure for determining the energy baseline are the main scientific results. This methodology was applied to a boiler house of a district heating system. Relevant variables were formed using a three-stage selection of factors that influence the gas consumption efficiency of the boiler house. Combinatorial algorithm of the group method of data handling was used for gas consumption simulation. The search for models of optimal complexity was performed in six classes of basic functions. The selection of better structures of the mathematical model was realized based on the criteria for its appropriateness (regularity, unbiasedness criterion, Schwartz, determination coefficient) and accuracy of the forecast using the morphological criterion. As a result, a multifactor mathematical model of optimal structure was obtained. The percent forecasting error did not exceed $1 \%$. The significance of the results lies in the fact that the proposed methodology can be applied to any facility.
\end{abstract}

Keywords: relevant variables of the energy baseline, mathematical model of energy consumption, group method of data handling.

DOI: https://doi.org/10.52254/1857-0070.2022.1-53.06

UDC: 620.91:658.24-047.58

Monitorizarea eficienței energetice a instalațiilor de încălzire urbană: metodologie pentru determinarea consumului de energie de referință

${ }^{1}$ Davâdenco L.V., ${ }^{1}$ Davâdenco N.V., ${ }^{1}$ Davâdenco V.A., ${ }^{2}$ Spreik D.

${ }^{1}$ Universitatea Națională Tehnică din Lușc, Luțc, Ucraina,

${ }^{2}$ Universitarea Glindor, Wreksham, Marea Britanie

Rezumat. Scopul lucrării este de a adapta nivelul de referinţă al consumului de energie la condițiile de funcționare a obiectului, în conformitate cu cerințele standardelor ISO 50000. Pentru a atinge obiectivul propus, se propune metodologia de determinare a nivelului de referință al consumului de energie, care conține procedura de formare a unui set de variabile determinante și procedura de construire a modelului multifactorial al consumului de energie. Cele mai importante rezultate știinţifice sunt următoarele: procedura în trei etape de selectare a factorilor care influențează consumul de energie permite luarea în considerare a importanței acestora, precum şi a posibilității de executare a elementelor de comandă, măsurare şi control; procedura de modelare a consumului de energie prin metoda de autoorganizare a modelelor, completată de analiza multicriterială a calităţii modelării, asigură construirea unui model multifactorial de structură optimă, propice pentru normalizarea consumului de energie de referință la variabilele definitorii. Setul de variabile determinante al nivelului de referință al consumului de energie este constituit folosind procedura propusă de selecție a factorilor care influențează eficiența consumului de gaz. Rezultatele analizei multicriteriale pentru a înțelege cât de adecvat este modelul au arătat că creșterea gradului de complexitate a modelului nu asigură o creștere considerabilă a calității de modelare. Semnificația rezultatelor: metodologia propusă este aplicabilă pentru orice obiect din sfera producerii, iar realizarea sa, completată de procedura de control a consumului de energie și a variabilelor determinante, permit nu doar stabilirea devierii valorii efective a consumului de energie față de cea planificată, dar și motivele în urma cărora acestea parvin.

Cuvinte-cheie: variabile determinante de referință ale consumului de energie, model matematic al consumului de energie, metoda de scontare în grup a argumentelor. 


\section{Мониторинг энергоэффективности объектов системы централизованного теплоснабжения: методология определения базового уровня энергопотребления \\ 1 Давыденко Л.В., ${ }^{1}$ Давыденко Н.В., ${ }^{1}$ Давыденко В.А., ${ }^{2}$ Спрейк Д. \\ 1 Луцкий национальный технический университет, Луцк, Украина, \\ 2 Университет Глиндор, \\ Рексем, Великобритания}

Аннотация. Определение базовых значений энергетической результативности является составляющей мониторинга энергоэффективности любых объектов. Целью работы является адаптирование базового уровня энергопотребления к условиям функционирования объекта в соответствии с требованиями стандартов ISO 50000. Для достижения цели предложена методология определения базового уровня энергопотребления, содержащая процедуру формирования набора его определяющих переменных и процедуру построения многофакторной модели энергопотребления. Наиболее существенные научные результаты: трехступенчатая процедура отбора факторов, влияющих на энергопотребление, позволяет учесть их значимость, а также их управляемость, возможность измерения и контроля; процедура моделирования энергопотребления с использованием метода самоорганизации моделей, дополненная многокритериальным анализом качества моделирования, обеспечивает построение многофакторной модели оптимальной структуры, пригодной для нормализации базового уровня энергопотребления к определяющим переменным. Применение методологии продемонстрировано на примере котельной системы централизованного теплоснабжения. Набор определяющих переменных базового уровня энергопотребления сформирован с помощью предложенной процедуры отбора факторов, влияющих на эффективность потребления газа. Структурно-параметрическая идентификация математической модели газопотребления выполнена с помощью комбинаторного алгоритма метода группового учета аргументов. Поиск моделей оптимальной сложности производился в шести классах базовых функций. Результаты многокритериального анализа адекватности моделей показали, что повышение сложности модели не обеспечивает существенного повышения качества моделирования. Лучшая структура модели выбрана на основе критериев регулярности, несмещенности, Шварца, коэффициента детерминации и точности прогноза с использованием морфологического критерия. В результате получена многофакторная математическая модель энергопотребления оптимальной структуры, ошибка прогнозирования которой не превышает $1 \%$. Значимость результатов: предложенная методология применима к любому производственному объекту, а ее использование, дополненное процедурой контроля энергопотребления и определяющих переменных, позволит не только установить отклонения фактического значения энергопотребления от запланированного, но и его причины.

Ключевые слова: определяющие переменные базового уровня энергопотребления, математическая модель энергопотребления, метод группового учета аргументов.

\section{INTRODUCTION}

According to the International Energy Agency (IEA), in the modern energy strategies of the EU countries, which are consumers of a considerable amount of energy resources, priority is given to the problem of energy efficiency [1]. Energy Efficiency Directive 2012/27/EU [2] and Directive (EU) 2018/2002 [3] requires the efficient use of energy in all areas. Directive (EU) 2018/2002 [3] sets a target to improve energy performance by at least $32.5 \%$ by 2030 . This requires a reduction in primary energy consumption by $26 \%$ and a reduction in final energy consumption by $20 \%$ compared to 2005 levels [3]. Regular evaluation of progress towards energy efficiency targets is provided by Regulation 2018/1999 of the European Parliament and of the Council [4]. The requirement of energy performance improvement is also mandatory for district heating systems (DHSs) and heat energy producers.

Energy performance improvement requires the introduction of energy-saving technologies, the improvement the efficiency of technological processes and energy consumption, and the development of the system of energy efficiency management. Issues of reducing energy consumption in heating systems are in the field of view of modern research.

Many scientific works are devoted to the study of improving the energy efficiency of the heat supply process by integration of a flue gas condensing unit and recovery of flue gas heat in boiler houses [5-8] and controlling the performance of boilers $[9,10]$, the transition to reduced temperature graphs of supply and return water [11-14], optimization of heat load to minimize the thermal peaks $[15,16]$ and thermal energy storage technologies $[17,18]$.

The results of this research indicate that the implementation of the proposed approaches and methodologies will reduce energy resource costs in a heating system. However, it should be noted that ensuring energy performance improvement 
of any complex technological system (CTS) and its facilities involves the management of energy consumption efficiency at all levels. The establishment of issues on energy consumption levels, the identification of facts of deviations from the set values, the reasons that caused these deviations, and making management decisions are the main stages of such management. Creation of mechanisms of control and comparison of the results with the set energy consumption targets is one of the recommendations of the IEA for energy performance improvement [1].

It is necessary to set the planned value of energy consumption to perform energy efficiency control. The energy baseline $(\mathrm{EnB})$ is a planned value according to the Energy Management Standard ISO 50001. The achievable/achieved energy performance at the facility is determined in comparison with an EnB. Thus, it is necessary to correctly determine the EnB in order to obtain correct results of control of energy consumption efficiency and making informed decisions to improve energy efficiency. The Energy Management Standard ISO 50001 [16] states that "EnB must be normalized to the variables that have an influence on energy consumption". EnB normalization procedure involves the construction of a mathematical model of energy consumption of the technological processes, taking into account the relevant variables. The accuracy of the results of energy consumption efficiency control depend on the quality of the mathematical model and the degree of its integrity. Therefore, solving the issue of the mathematical model construction, which is used to determine the EnB at the facility, is an important issue. As such, it should take into consideration the features of the functioning of the research object. Unfortunately, the Standards ISO 50000 [16-18] contain general recommendations for the construction and verification of an EnB. However, the standard does not specify how to form a set of relevant variables to create an EnB for a specific facility, which method of structural and parametric identification of a mathematical model to choose, and how to choose a better structure of a mathematical model when the type of connection between variables is unknown.

The answers to these questions take into consideration the specifics of the facility being analyzed and are different in various research studies already carried out. For example, in [22], the linear regression model is used to establish the applied energy baseline for multiple production from a single raw material. The model construc- tion is carried out for each type of product produced by plastic injection machine and the equivalent production method is applied. The authors of [23] take into account the nature of the relationship between energy performance indicators (EnPIs) and impact factors in order to construct the energy baseline models of EnPIs of chemical industry facilities. The multifactor linear regression model for $\mathrm{EnB}$ is used in the case of linear coupling. In the case of a nonlinear relationship, a method combining Particle Swarm Optimization and Gauss-Newton algorithm is proposed to construct a multifactor energy baseline model. In [24], the productivity factor is considered as EnPI of the chiller system and compares the results of application of different machine learning methods (Linear regression, Lee simplified model, Multivariate polynomial regression, artificial neural network (ANN), Random forest, XGBoost) to construct a multifactor energy baseline model of EnPI. The maximal information coefficient was used to determine a measure of the strength of the linear or nonlinear association between EnPI and the influencing factors. In [25], ANNs are used to construct the energy baseline of the chiller system, and 81 ANN structures are analyzed to select the best model. In [26], two approaches are compared to determine the baseline energy consumption of cogeneration plant of a CHP plant: thermodynamic modeling and ANNs, and ANNs are considered promising for assessing baseline consumption in energy-intensive industry. The authors of [27] compare the models constructed by the multilayer perceptron method and linear regression to construct the EnB model. The MLP model is considered more reliable, especially when the plant is expanding capacity.

Regarding the facilities of the DHS, the issue of EnB construction is widely considered for buildings as end heat consumers. In [28], the adaptive neuro-fuzzy inference system (ANFIS) was applied to determine the relevant variables of the consumer heat load model in DHSs. The authors of [29] consider machine learning algorithms (regression trees, random forest and regression support vector machines) to construct the energy baseline model of annual heat consumption and identify the most influential technical and behavioral parameters on heat consumption of final consumers in DHSs. In [30], the Eclat algorithm of the association rules was applied to select the best combination of input parameters of the heat load model. The authors compare the results of its work with the Spear- 
man parameter selection method. Eclat-Support Vector Regression (E-SVR) and SpearmanSupport Vector Regression (S-SVR) prediction models were used to determine heat load, and their performance was investigated.

From the given examples, it is possible to see that researchers offer many different approaches to solving an issue of EnB definition. Each proposed solution takes into account the specifics of energy consumption of the research object. This indicates that the issue of developing a mechanism for determining the EnB of the DHS facilities, taking into account their operation conditions, requires special attention.

It should be noted that the definition of EnB is the basis for identifying moments of inefficient energy consumption, as well as the reasons for these deviations, and making management decisions to further prevent such situations. Therefore, the EnB model should take into account the main characteristics (relevant variables) that have an influence on energy consumption efficiency. At the same time, these characteristics should not only have a significant impact on power consumption, but also be easily measured or calculated based on the other easily measurable characteristics. In addition, these characteristics have to be variable as well as easily controlled to determine the reasons for the discrepancy between actual and planned energy consumption. Therefore, the formation of a set of relevant variables of $\mathrm{EnB}$ with the condition of simultaneous consideration of the materiality of influence of the variable on energy consumption, its measurability, controllability and control is the first issue that needs to be solved for the EnB determination. However, in the works of researchers the main emphasis is placed on the degree of influence of the factor on the energy consumption process, and the issues of its controllability and control remain out of consideration.

The construction of energy consumption model to normalize EnB to the relevant variables is the next issue. The complexity of mathematical simulation of energy consumption of any facility is due to the need to take into consideration many factors that have an influence on the energy consumption, information about which is contained in the results of observations. Various methods of mathematical simulation are applied for simulation of the energy consumption of different facilities based on the experimental data, in particular, multifactor regression analysis [27, 31-34], apparatus of artificial neural networks [25-27, 35-38], neuro-fuzzy conclusion [28, 39,
40] and others machine learning methods [24, $29,30,41]$. The analysis of features of methods and the review of examples of their application allows asserting that each method has its advantages, disadvantages, and limits of application. However, the application of these methods in some cases is complicated by the difficulty of determining the structure of relationship between relevant variables and energy consumption (eg, multifactor regression analysis) or by the small amount of experimental data (e.g., ANNs and other machine learning methods). It should be noted that researchers are focusing on ensuring the predictive capacity of models during the solving of the issue of mathematical modeling of energy consumption. However, the energy consumption model should not only provide an adequate definition of $\mathrm{EnB}$, but also be suitable for solving the issues of control of energy consumption efficiency.

The purpose of the article is to improve the mechanism of monitoring the energy efficiency of CTS by developing a methodology for constructing the EnB, which would take into account the operation conditions of the facility and the ISO 50000 Standards requirements. It has to provide solutions to the following issues: the formation of the set of relevant variables influencing the energy consumption, structural and parametric identification of the mathematical model of energy consumption to normalize the $\mathrm{EnB}$ to the relevant variables, and evaluation of its predictive capacity.

The three-stage procedure for forming a set of relevant variables of $\mathrm{EnB}$, which allows taking into account the importance of variables, their measurability, controllability and control, as well as the procedure for constructing a multifactor model of optimal structure for EnB are proposed to achieve the purpose.

The developed methodology is suitable for determining the EnB of any CTS or its facilities. Its application as a part of an energy efficiency monitoring system, together with procedures for controlling energy consumption and relevant variables, will help not only to identify the deviations of actual energy consumption from the planned value, but also the reasons for this.

\section{METHODS OF RESEARCH}

1. Statement of the issue of energy consumption simulation. Energy consumption in the CTS depends on the technological and technical characteristics, operation mode parameters 
and environmental conditions. However, it is complicated to take into account all the factors and their relationships, as well as to perform a mathematical description of the physical relationship between factors and energy consumption. Therefore, it is necessary to use mathematical simulation methods based on experimental data, that is, measurements of the energy consumption and variables that characterize the technological process and its efficiency to construct a mathematical model of energy consumption. Simulation of the energy consumption of any facility to determine the EnB requires solving the following issues: the selection of relevant variables, the formation of a set of statistic data, the selection of the model structure, the evaluation of model parameters and its suitability.

2. Methodology of formation of the set of relevant variables of the EnB. The system under study is described by a finite set of indicators. Moreover, each of the indicators in its content belongs to a certain group, which characterizes the features of energy consumption. Defining a sufficiently complete set of variables that have a significant influence on the energy consumption of the facility, ordering a set of variables and determining enough informative relevant variables of the EnB is an important stage of the simulation procedure.

Formation of a set of relevant variables should be performed taking into consideration the experience of experts in this field. It is appropriate to use the Delphi method [42]. This method allows forming a set of the most informative variables (significant) by ranking them and testing a hypotheses about the presence of a certain structure of the influence of factors. The method also allows ensuring the objectivity of the opinions of experts by evaluating their consistency [42]. However, the formation of the initial set of variables that should be taken into consideration is key during its application. There is a difference of opinion on the need to enter a parameter into the questionnaire for ranking. The reasons for this situation are: the level of automation of statistical information collection, which determines the appropriate attitude of experts to the possibility of determining a certain parameter; the method of gaining experience of the expert, which is determined by the place of its acquisition; the type of tasks, for solving of which informative variables are selected. A three-stage procedure for forming a set of relevant variables of $\mathrm{EnB}$ was proposed in the paper to solve this problem.
Stage 1 - the formation of a set of informative variables. The issue of formation of the set of informative variables is proposed to consider from positions of multicriteria selection. The principles of multicriteria ordinal classification, which does not require the ranking of variables, is the basis of this selection. It is enough to distribute them between several classes, ordered by the degree of reflection of a certain property. A set of selection criteria, which are aggregated into a composite criterion, is the basis for selection. This criterion determines the degree of influence of the variable on the target variable. The issue is as follows: a set of variables, which must be attributed to one of the $M$ ordered classes $C_{1}, \ldots, C_{M}$, is specified. Each variable to be classified is characterized by a combination of scores by $N$ characteristics $K_{1}, \ldots, K_{n}$, which have detailed verbal formulations of quality gradations, which are ordered by the expert from more characteristic to less characteristic [43, 44]. Selective criterion $K_{1}$ characterizes the degree of influence on the process, criterion $\mathrm{K}_{2}$ characterizes the degree of measurement and control, criterion $\mathrm{K}_{3}$ characterizes the degree of controllability and variability (Figure 1). The criteria have a scale of scores $X_{i}$ with three verbal ordinal scores $0,1,2$, where 0 means the best score, 1 means middle score, 2 means worse score. The composite criterion of the upper level characterizes the degree of informativeness of the variable, the gradations of estimates of which (high, good, middle, low, unsatisfactory) determine 5 ordered classes of solutions.

The usage of the method of multicriteria selection allows the performing of the gradation of variables on certain qualitative features that characterize its properties. This gives an opportunity to avoid differences of opinion between experts on the feasibility of considering the influence of the variable on the solution of the set issue. Structural classification gives an opportunity to convert the intuitive knowledge of experts and their verbal evaluations into quantitative scores. This then allows the combining these scores into groups that have a specific meaning. A stratification scale, that is, an interval scale, in which each stratum contains a certain set of variables that are united by common features, was applied to group variables based on the scores obtained from experts. The variable that belongs to the class $\mathrm{C}_{1}$ based on the consistent classification obtained the score 5 . The variable that belongs to the class $\mathrm{C}_{2}$ obtained the score 4 . The variable that belongs to the class $\mathrm{C}_{3}$ obtained the 
score 3 . The variable that belongs to the class $\mathrm{C}_{4}$ obtained the score 2 . The variable that belongs to the class $\mathrm{C}_{5}$ obtained the score 1 .

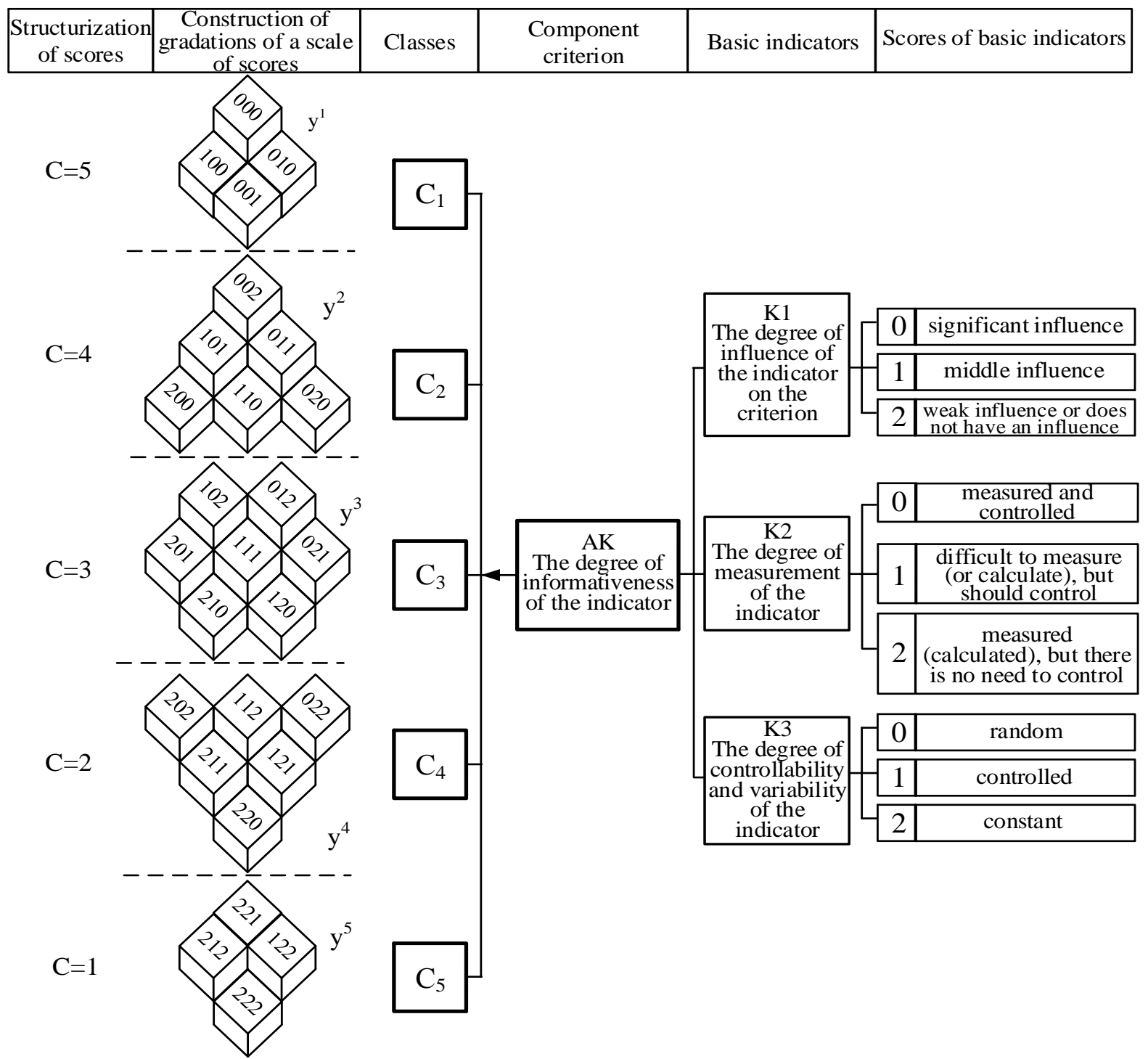

Fig. 1. Scheme of multicriteria classification of variables that have an influence on the energy consumption efficiency.

Then the average score $\bar{B}$ was calculated, based on which the stratums were constructed:

5th stratum: $4<\bar{B} \leq 5$ - variables that definitely have a significant influence and require mandatory consideration;

4th stratum: $3<\bar{B} \leq 4-$ variables that have a significant influence and are recommended for consideration;

3rd stratum: $2<\bar{B} \leq 3$ - variables that have a rather significant influence and can be taken into consideration;

2nd stratum: $1<\bar{B} \leq 2$ - variables that have a weak influence and can be ignored;

1st stratum: $\bar{B} \leq 1$ - variables that have a very weak influence and do not require consideration.
A set of informative variables is formed based on the obtained groups of variables that characterize the degree of their influence on the studied process or target characteristic.

Stage 2 - formation of a set of essential informative variables. The Delphi method was applied to the formed set of informative variables. Verification the consistency of expert's scores by means of the concordance coefficient $W$ and the significance of the concordance coefficient $W$ according to the Pearson's chi-squared test, as well as the significance of the difference of selected variables according to Student's t-test, was performed [42].

The main stages of the procedure of selection of significant variables that have an influence on 
the energy consumption efficiency of the facility, based on expert scores are presented in Figure 2.

The formation of sets of significant variables of the EnB for the selected research object is the result of the proposed procedure.

Stage 3 - assessment of the degree of relationship between variables and selection of relevant variables of EnB.

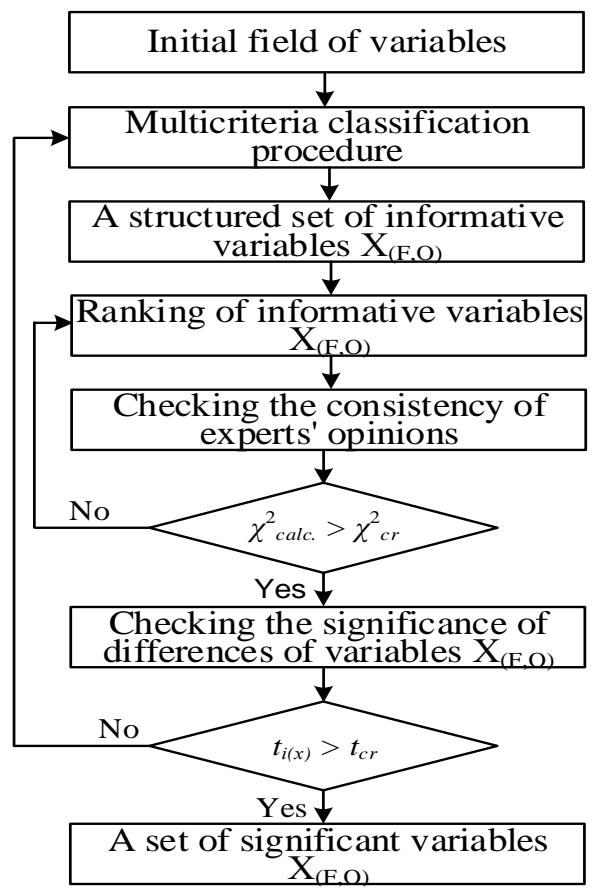

Fig. 2. The procedure for selecting significant variables that have an influence on the energy consumption efficiency of the facility.

A sample pairwise correlation coefficient was used to estimate the relationship between variables. It should be noted that taking into account the input variables that have a small influence in the energy consumption model complicates the simulation procedure. However, their neglect makes it impossible to trace the reasons that led to inefficient energy consumption. Therefore, the formation of a final set of relevant variables of $\mathrm{EnB}$ involves a logical analysis of the relationship between energy consumption and variables that have an influence on its efficiency.

3. Methodology of mathematical simulation of energy consumption. The complexity of mathematical simulation of energy consumption of any facility is due to the need to take into consideration many factors that have an influence on the energy consumption, information about which is contained in the results of observations. To construct the mathematical model, it is necessary to determine its structure and evaluate the parameters, that is, to solve the issue of structural and parametric identification of the model by the sampling of experimental data.

The choice of method for solving a specific practical issue is a separate and quite difficult task. Any facility has a unique nature of energy consumption and complex connections between energy consumption and many factors that have an influence on it.

Let the value of the output variable (gas consumption) be $y^{j}$ and a number of input parameters $x_{i}^{j}:\left\{y^{j}, x^{j}\right\},\{i=1, \ldots, m ; j=1, \ldots, n\}$ that are obtained by the results of $n$ observations. Based on the obtained data, it is necessary to determine the dependency $Y=f\left(x_{1}, x_{2}, \ldots, x_{m}\right)$ that best describes the interconnection between the input parameters and the output variable. It should be noted that the degree of influence of factors on energy consumption, model structure and mechanism of the relationship between the factors are unknown. In this case, the construction of the energy consumption model should be carried out using selforganization methods. The group method of data handling (GMDH) is one of the methods that provides a solution to the problem of construction a power consumption model in conditions of uncertainty. In this case, the GMDH algorithm does not require specifying the type of model, the characteristics of the relationships between factors, etc., and automatically performs structural-parametric identification of the mathematical model based on experimental data [45, 46]. Retrospective data samples of volume $n$ for $m$ relevant variables $X$, as well as energy consumption $W$, are input variables of the model synthesis algorithm. The formation of sets of modelscandidates, each of which is optimal in a given class of basic functions, is the result of the algorithm of a models synthesis (Figure 3).

Verification of the adequacy of the mathematical model is performed by the internal criterion $\Delta^{2}(\mathrm{~A})$, the forecast error variation criterion $\delta^{2}$, and the determination coefficient $R^{2}$ [46]. The GMDH algorithm finds the optimal model in each given class of reference functions by the regularity criterion $\Delta^{2}(\mathrm{~B})$ and the unbiasedness criterion $n_{u n b}^{2}$, which are external criteria [35]. In order to choose the best structure of the model, it is necessary to perform not only the analysis of its adequacy, but also the assessment of the accuracy of the forecast $\Delta^{2}(\mathrm{C})$ [46]. The degree of complexity of the model structure should also be taken into account. For this purpose, it is expedi- 
ent to apply Schwarz's information criterion $B I C$. That is, the selection of a better structure of the mathematical model of energy consumption of the research object involves the usage of multicriteria selection of model. In this case, the criteria should not duplicate each other.

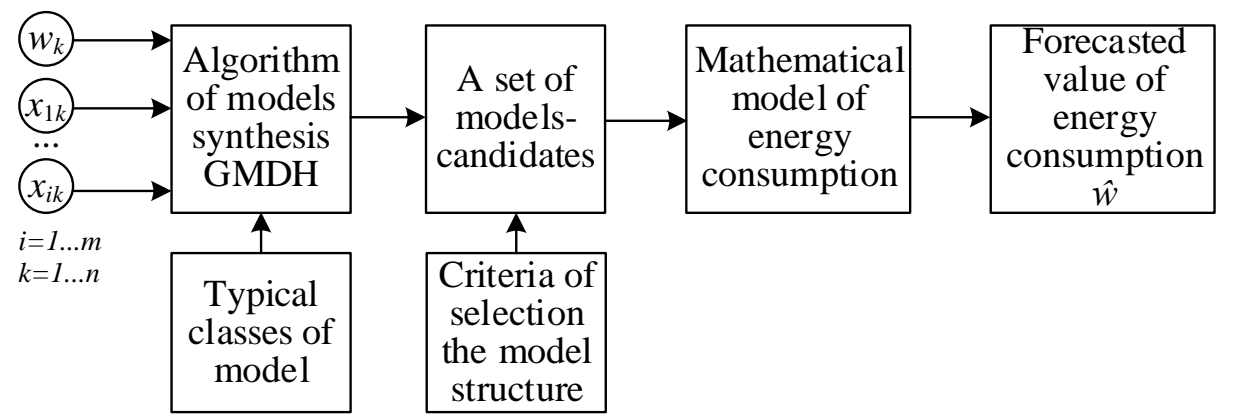

Fig. 3. Procedure of construction of mathematical model of energy consumption.

Therefore, the choice of the best structure of the model involves the simultaneous consideration of such conditions:

$$
\begin{aligned}
& \Delta^{2}(B) \rightarrow \min ; \quad n_{u n b}^{2} \rightarrow \min ; \\
& R^{2} \rightarrow \max ; \quad B I C \rightarrow \min ; \quad \Delta^{2}(C) \rightarrow \min .
\end{aligned}
$$

In this case, it is possible when one model is better by one criterion, and another model is better by another criterion. Therefore, it is advisable to apply the morphological criterion in order to select the best structure of the mathematical model from the candidate models. The idea of the method is described in our previous research. The method provides calculating the area of a figure whose vertices are the normalized values of the criteria (1). First, an inverse value Toler $=1-R^{2}$ is introduced for the coefficient of determination. Then all the criteria are expressed in relation to their maximum value and are presented in the form of a figure given by vertices with coordinates $\left(x_{i}, y_{i}\right)$. The constructed figure is a chart radar type (CRT), the vertices number of which corresponds to the number of criteria.

The model for which the area of CRT is the smallest should be considered the best. Determination of the predicted value of the output variable, that is, the value of the energy baseline, is the result of the application of the proposed modeling procedure.

\section{RESULTS}

The proposed methodology was used for the construction of an EnB for the boiler house of the DHS. Fuel, electric power, and water are consumed for the heat production by the boiler house of the DHS. Fuel (gas) is the main energy resource consumed by the boiler house.
1. Analysis of the factor field of factors that have an influence on the gas consumption efficiency at the boiler house. The fuel consumption at the boiler house depends on many factors: the technical characteristics of the boiler, the characteristics of the fuel, the organization of the heating process, the unique needs of the boiler house, etc. It is also necessary to take into consideration the load chart of the boiler house, which varies depending on the air temperature.

The technical characteristics of the boiler include the following: boiler power; passport energy conversion efficiency (ECE) of the boiler; normative fuel consumption at rated load; average annual boiler load for the last year; normative coefficient that characterizes the presence (absence) of heat utilization equipment; the coefficient of excess air in the fire-chamber of the boiler; lower heat of fuel combustion on which the boiler operates during the previous year; ECE of the boiler at a given load, determined by the results of tests for mode adjustment on this type of fuel; ECE of the boiler depending on operation term.

The ECE of boilers, depending on the operation term, is taken based on the results of the data of the mode characteristic or calculated taking into consideration the appropriate normative coefficient of the ECE decrease. The mode characteristic is obtained during the last tests for mode adjustment. The normative coefficient is differentiated and depends on the standard size of the boiler and its operation term. It characterizes the average static decrease of the ECE and increase of the fuel consumption norm by boilers of different designs depending on their physical aging during its operation process. The actual ECE of boilers depends on the conditions and terms of their operation and the types of fuel burned in 
the boiler. It should take into consideration the actual ECE decrease that occurs due to equipment wear, under loading of the boiler, due to accidents and unaccounted heat consumption. Utilization of flue gas heat allows increasing the ECE of the boiler and reduce fuel consumption by $1 \mathrm{Gcal}$ of heat produced. Therefore, the actual value of the flue gas temperature also has an influence on the gas consumption efficiency.

The efficiency of the boiler operation depends on the organization of energy consumption mode. Therefore, it is necessary to consider indicators that would reflect fuel consumption efficiency. Given the irregularity of the heat load chart, it is necessary to take into consideration the value of specific fuel consumption according to the results of mode adjustment at maximum, middle and minimum boiler loads, boiler load coefficient at maximum, middle and minimum load, and boiler operation time at maximum, middle and minimum loads.

Operation modes of the boiler house during the heating period is determined by the temperature chart of the central regulation of heating systems. This schedule is formed for the boiler house taking into consideration the heat load, the technical condition of heating systems, their operation conditions, etc. It determines the temperature of the coolant, which must be maintained at the inlet and outlet of the heating system depending on the outside air temperature. The temperature of the outside air during the heating period is another factor that has an influence on the amount of gas consumption for heat production in the boiler house. The dynamics of changes in air temperature has a significant influence on the dynamics of gas consumption.

It should be noted that some factors are more manageable and can be easily changed in the process of improving the technological process. Other factors are less manageable, their changes are impossible or complicated for technical reasons (for example, require equipment upgrades). Manageable parameters will be converted to optimal values due to the ensuring of efficient operation mode of boilers in terms of gas consumption. The variation of these parameters will decrease, and their variance will decrease. This will reduce the variance in the value of energy consumption caused by the influence of these parameters. Therefore, it is impractical to take into consideration parameters with a low level of variation in the gas consumption model to determine the EnB. It should also be considered that some variables are complicated to measure and control. Therefore, their consideration in the gas consumption model will complicate data collection to determine the EnB. However, there are other interrelated technological parameters that are easy to measure and control.

2. Formation of the set of relevant variables of the EnB. The group of experts was asked to evaluate each variable of the initial factor field to form the set of informative variables that have an influence on the gas consumption of the boiler house. They used the generated selection characteristics for this. A survey of experts was carried out using a questionnaire containing a list of variables of the factor field. The experts did not evaluate the variables, which in their opinion should not be used in each issue statement. These variables were automatically obtained a score of zero points. The experts also added new variables that they believe should be taken into consideration. The average score for each variable from the initial factor field was determined based on the results of processing the questionnaires received from the experts. Based on this, the variable was added to one of the stratums according to the degree of influence on the gas consumption of the boiler house. The results of grouping variables are given in Table 1 .

Then the Delphi method was applied, variables were rated, and the consistency of experts' opinions and the significance of the difference of selected variables were checked. The ranking results of the variables given in Table 1 that have an influence on the gas consumption efficiency of the boiler house, showed the irregularity and variation of their influence (Figure 4).

Checking the consistency of expert's opinions with the help of the concordance coefficient W confirmed the high level of connection between the expert's scores $(\mathrm{W}=0,898)$. Evaluation of the significance of the concordance coefficient $\mathrm{W}$ by Pearson's chi-squared test proves not random agreement of expert's opinions $\left(\chi_{\text {calc }}^{2}=158,4>\chi_{c r}^{2}=18,9\right)$.

The exhaust gases temperature $\left(\mathrm{x}_{1}\right)$; oxygen content in the exhaust gases $\left(\mathrm{x}_{2}\right)$; the temperature of water supplied to the system $\left(\mathrm{x}_{3}\right)$; the temperature of water returned from the system $\left(\mathrm{x}_{4}\right)$; water consumption in the supply pipe of the heat supply system $\left(\mathrm{x}_{5}\right)$; the water consumption for compensation the water losses of the heat system $\left(\mathrm{x}_{6}\right)$; gas pressure $\left(\mathrm{x}_{7}\right)$; air temperature $\left(\mathrm{x}_{8}\right)$ are variables that have an influence on the gas consumption efficiency in the boiler house. 
Table 1

The results of grouping variables that affect the gas consumption efficiency of the boiler house.

\begin{tabular}{|c|c|c|}
\hline Stratum & The content of the stratum & $\begin{array}{l}\text { Variables that have an influence on gas con- } \\
\text { sumption }\end{array}$ \\
\hline Fifth & $\begin{array}{l}\text { Variables that have a significant influence } \\
\text { and must be taken into consideration during } \\
\text { the model construction }\end{array}$ & $\begin{array}{c}\text { temperature of the water supplied to the system; } \\
\text { temperature of water returned from the system; } \\
\text { air temperature; }\end{array}$ \\
\hline Fourth & $\begin{array}{c}\text { Variables that have a significant influence } \\
\text { and should be taken into consideration dur- } \\
\text { ing the model construction }\end{array}$ & $\begin{array}{c}\text { gas pressure; water consumption for compensa- } \\
\text { tion the water losses of the heating system; } \\
\text { exhaust gas temperature; }\end{array}$ \\
\hline Third & $\begin{array}{l}\text { Variables that have a rather significant influ- } \\
\text { ence and can be taken into consideration dur- } \\
\text { ing the model construction }\end{array}$ & $\begin{array}{c}\text { oxygen content in exhaust gases; } \\
\text { water consumption in the supply pipeline of the } \\
\text { heating system; }\end{array}$ \\
\hline Second & $\begin{array}{l}\text { Variables that have a weak influence and can } \\
\text { be ignored during the model construction }\end{array}$ & $\begin{array}{l}\text { boiler load coefficient at a set load; boiler oper- } \\
\text { ation time at a set boiler load; } \\
\text { actual ECE decrease; }\end{array}$ \\
\hline First & $\begin{array}{l}\text { Variables that have a very weak influence } \\
\text { and should not be taken into consideration } \\
\text { during the model construction }\end{array}$ & $\begin{array}{l}\text { boiler power; passport ECE of the boiler; } \\
\text { ECE of the boiler at the set load; ECE of the } \\
\text { boiler depending on the operation term. }\end{array}$ \\
\hline
\end{tabular}

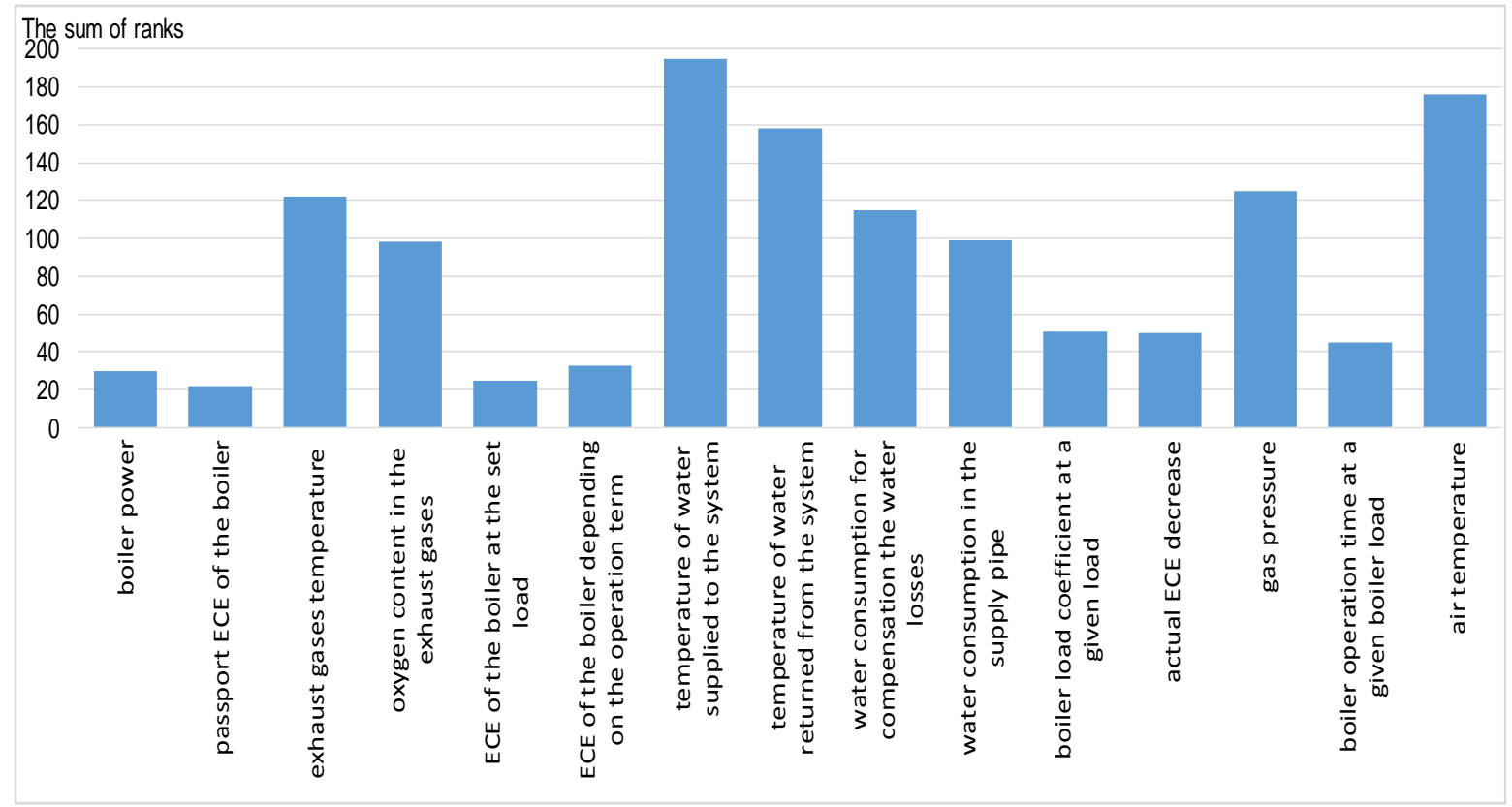

Fig. 4. The result of ranking the variables that have an influence on the efficiency of gas consumption of the boiler house.

The significance of the difference of the selected factors was checked according to Student's t-test and it was established that the difference between the factors is not random. The variables selected by the Delphi method belong to 1-3 strata (Table 1), which contain variables that need to be taken into consideration in the mathematical model of gas consumption. Thus, the obtained results confirmed the results of grouping variables based on the multicriteria ordinal classification. Therefore, the acceptance or nonacceptance of a certain variable and the for- mation of a set of presumably informative variables is substantiated.

For the selected variables, the database that includes daily statistics of retrospective manufacturing indicators and actual gas consumption is created. These data were obtained from the boiler house operation mode monitoring system.

The analysis of the results of correlation analysis (Table 2) allows asserting that the selected variables should be taken into consideration during construction the mathematical model of gas consumption of the boiler house. 
Correlation coefficients.

\begin{tabular}{|c|c|c|c|c|c|c|c|c|}
\hline $\mathrm{Y}$ & $\mathrm{x}_{1}$ & $\mathrm{X}_{2}$ & $\mathrm{x}_{3}$ & $\mathrm{X}_{4}$ & $\mathrm{X}_{5}$ & $\mathrm{X}_{6}$ & $\mathrm{X}_{7}$ & $\mathrm{x}_{8}$ \\
\hline 1,00 & 0,67 & 0,45 & 0,85 & $-0,81$ & 0,54 & 0,33 & $-0,34$ & $-0,68$ \\
\hline
\end{tabular}

3. Construction of the mathematical model of gas consumption of the boiler house. A combinatorial GMDH algorithm was selected for gas consumption simulation. Simulation was accomplished in the software GMDH Shell DS 3.8.3 [48]. Six classes of reference functions were selected in which the optimal model was searched (Table 3). The GMDH algorithm performs a model construction (estimation of its coefficients) on the training sample and a selection of the optimal structure of the model by checking the model on the test sample for the whole set of models in each class of reference functions. K-fold validation was selected as a model validation strategy [47]. A selection of models of optimal complexity in each class of reference functions is the result of the GMDH algorithm. These models provide a minimum of the internal criterion $\Delta^{2}(\mathrm{~A})$, the forecast error variation criterion $\delta^{2}$, and the maximum of the determination coefficient $R^{2}$ (they were calculated on the training sample), as well as the regularity criterion $\Delta^{2}(\mathrm{~B})$, the unbiasedness criterion $n_{u n b}^{2}$ in the selected class of functions (they were calculated on the test sample). Schwarz's criterion $B I C$ was used to assess the complexity of the model structure.

Description of classes of basic functions.

\begin{tabular}{|c|c|c|}
\hline Class & Model characteristic & $\begin{array}{l}\text { Mathematical expression of the } \\
\text { model }\end{array}$ \\
\hline 1 & linear description models & $y=a_{0}+\sum_{i=1}^{M} a_{i} x_{i}$ \\
\hline 2 & linear description models with interaction effect & $y=a_{0}+\sum_{i=1}^{M} a_{i} x_{i}+\sum_{i=1}^{M} \sum_{j=1}^{M} a_{i j} x_{i} x_{j}$ \\
\hline 3 & nonlinear description models with limitation degree $p=2$ & \multirow{2}{*}{$y=a_{0}+\sum_{i=1}^{M} a_{i} x_{i}^{p}$} \\
\hline 4 & nonlinear description models with limitation degree $p=3$ & \\
\hline 5 & $\begin{array}{l}\text { polynomial models with interaction effect and limitation } \\
\text { degree } p=2, q=2\end{array}$ & \multirow{2}{*}{$y=a_{0}+\sum_{i=1}^{M} a_{i} x_{i}^{p}+\sum_{i=1}^{M} \sum_{j=1}^{M} a_{i j} x_{i}^{p} x_{i}^{q}$} \\
\hline 6 & $\begin{array}{l}\text { polynomial models with interaction effect and limitation } \\
\text { degree } p=3, q=3\end{array}$ & \\
\hline
\end{tabular}

The accuracy of the forecast $\Delta^{2}(\mathrm{C})$ (calculated on the control sample, which was not used to construct the model and verify its adequacy) was taken into account to assess the predictive capacity of the model. Results are given in the Table 4.

The analysis of the obtained results of evaluation the model's adequacy and the forecast accuracy (Table 4) does not give an exact answer about the better structure of the model. The morphological criterion was applied to select better a model from models-candidates. For this purpose, the normalized values of the criteria were calculated, the coordinates of the vertices of the CRT were determined and the area of the formed figure was calculated (Table 5). A better structure of the gas consumption model was selected based on the analysis of the obtained results. A mathematical model, to which the figure with smaller area corresponds, is better. Linear description model with interaction effect (class №2) is better.

4. Analysis of the results of the gas consumption simulation of the boiler house. Simulation results of the gas consumption of the boiler house based on the selected model for the winter months of the heating season are shown in Figure 5. A control sample was formed by uniformly point's selection from the initial sample. The chart of the deviations of the gas consumption values obtained based on the model, from the actual values is shown in Figure 6. Simulation results (Table 6) indicate that deviation does not exceed $1 \%$. 
Table 4

Mathematical gas consumption models and their characteristic.

\begin{tabular}{|c|c|c|c|c|c|c|c|c|}
\hline \multirow{2}{*}{$\begin{array}{c}\text { Class of } \\
\text { basic } \\
\text { function }\end{array}$} & \multirow[b]{2}{*}{ Type of model } & \multicolumn{7}{|c|}{ Characteristics of the mathematical model } \\
\hline & & $\Delta^{2}(\mathrm{~A})$ & $\Delta^{2}(\mathrm{~B})$ & $n_{u n b}^{2}$ & $\delta^{2}$ & $R^{2}$ & BIC & $\Delta^{2}(\mathrm{C})$ \\
\hline №1 & $\begin{array}{c}\mathrm{W}=-191,75+1,31 * \mathrm{x}_{1}+3,27 * \mathrm{x}_{3}+ \\
+10,99 * \mathrm{x}_{4}+11,23 * \mathrm{x}_{6}-1,95 * \mathrm{x}_{7}+14,56 * \mathrm{x}_{8}\end{array}$ & 0,00091 & 0,0052 & 20,00059 & 0,0011 & 0,9942 & 0,067 & 0,0036 \\
\hline №2 & $\begin{array}{c}\mathrm{W}=138,7+0,31 * \mathrm{x}_{1}-0,15 * \mathrm{x}_{1} * \mathrm{x}_{2}+ \\
+15,27 * \mathrm{x}_{3}-1,27 * \mathrm{x}_{3}{ }^{*} \mathrm{x}_{4}+18,99 * \mathrm{x}_{4}+ \\
+11,23 * \mathrm{x}_{6}-3,5 * \mathrm{x}_{5} * \mathrm{x}_{6}+ \\
+1,95 * \mathrm{x}_{7}+2,56 * \mathrm{x}_{8} * \mathrm{x}_{3}\end{array}$ & 0,00019 & 0,0016 & 50,00021 & 0,00001 & 0,9992 & 0,0325 & 50,0021 \\
\hline №3 & $\begin{array}{c}\mathrm{W}=10,71+0,031 * \mathrm{x}_{1}{ }^{2}+0,27 * \mathrm{x}_{3}{ }^{2}+ \\
+0,99 * \mathrm{x}_{4}{ }^{2}+1,23 * \mathrm{x}_{6}{ }^{2}-2,25 * \mathrm{x}_{7}{ }^{2}+ \\
+14,56 * \mathrm{x}_{8}{ }^{2}\end{array}$ & 0,00093 & 30,0029 & 0,0185 & 0,000031 & 10,9992 & 0,094 & 0,0026 \\
\hline №4 & $\begin{array}{l}\mathrm{W}=127,71+0,17 * \mathrm{x}_{1}{ }^{3}+0,7 * \mathrm{x}_{3}{ }^{3}+ \\
+1,22 * \mathrm{x}_{4}{ }^{3}-0,25 * \mathrm{x}_{7}{ }^{3}+1,56 * \mathrm{x}_{8}{ }^{3}\end{array}$ & 0,0022 & 0,0043 & 30,00018 & 0,00021 & | 0,9982 & 0,064 & 0,0048 \\
\hline №5 & $\begin{array}{c}\mathrm{W}=18,7+17,5 * \mathrm{x}_{1}-2,15 * \mathrm{x}_{1} * \mathrm{x}_{2} \\
+19,9 * \mathrm{x}_{4}+2,56 * \mathrm{x}_{8} * \mathrm{x}_{3}+0,27 * \mathrm{x}_{3}{ }^{2-} \\
-0,07 * \mathrm{x}_{3}{ }^{*} \mathrm{x}_{4}{ }^{2}+5,73 * \mathrm{x}_{6}-3,5 * \mathrm{x}_{5} * \mathrm{x}_{6}{ }^{2}+ \\
+2,08 * \mathrm{x}_{7}{ }^{2}-0,12 * \mathrm{x}_{8} * \mathrm{x}_{4} \\
\end{array}$ & 0,00089 & 0,0027 & 0,00058 & 0,000027 & 70,9992 & 0,079 & 0,002 \\
\hline №6 & 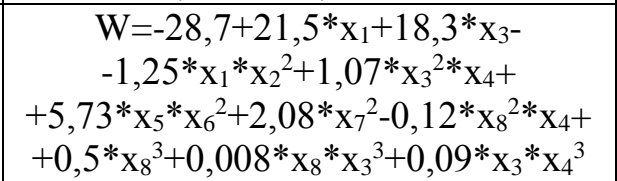 & 0,00019 & 0,0099 & 0,00027 & 0,0018 & 0,9998 & 0,022 & 0,0077 \\
\hline
\end{tabular}

Table 5.

Normalized values of the criteria of models adequacy.

\begin{tabular}{|c|c|c|c|c|c|c|}
\hline \multirow{2}{*}{ Class of basic function } & \multicolumn{5}{|c|}{ Adequacy criteria } & \multirow{2}{*}{ Area } \\
\cline { 2 - 6 } & $\Delta^{2}(\mathrm{~B})$ & $n^{2}{ }_{\text {unb }}$ & $R^{2}$ & BIC & $\Delta^{2}(\mathrm{C})$ & \\
\hline №1 & 0,525 & 0,032 & 1 & 0,713 & 0,468 & 0,512 \\
\hline №2 & 0,162 & 0,011 & 0,138 & 0,346 & 0,273 & $\mathbf{0 , 3 3 7}$ \\
\hline №3 & 0,293 & 1 & 0,138 & 1 & 0,338 & 1,231 \\
\hline №4 & 0,434 & 0,010 & 0,310 & 0,681 & 0,623 & 0,423 \\
\hline №5 & 0,273 & 0,031 & 0,138 & 0,840 & 0,260 & 0,713 \\
\hline №6 & 1 & 0,015 & 0,034 & 0,234 & 1 & 0,857 \\
\hline
\end{tabular}

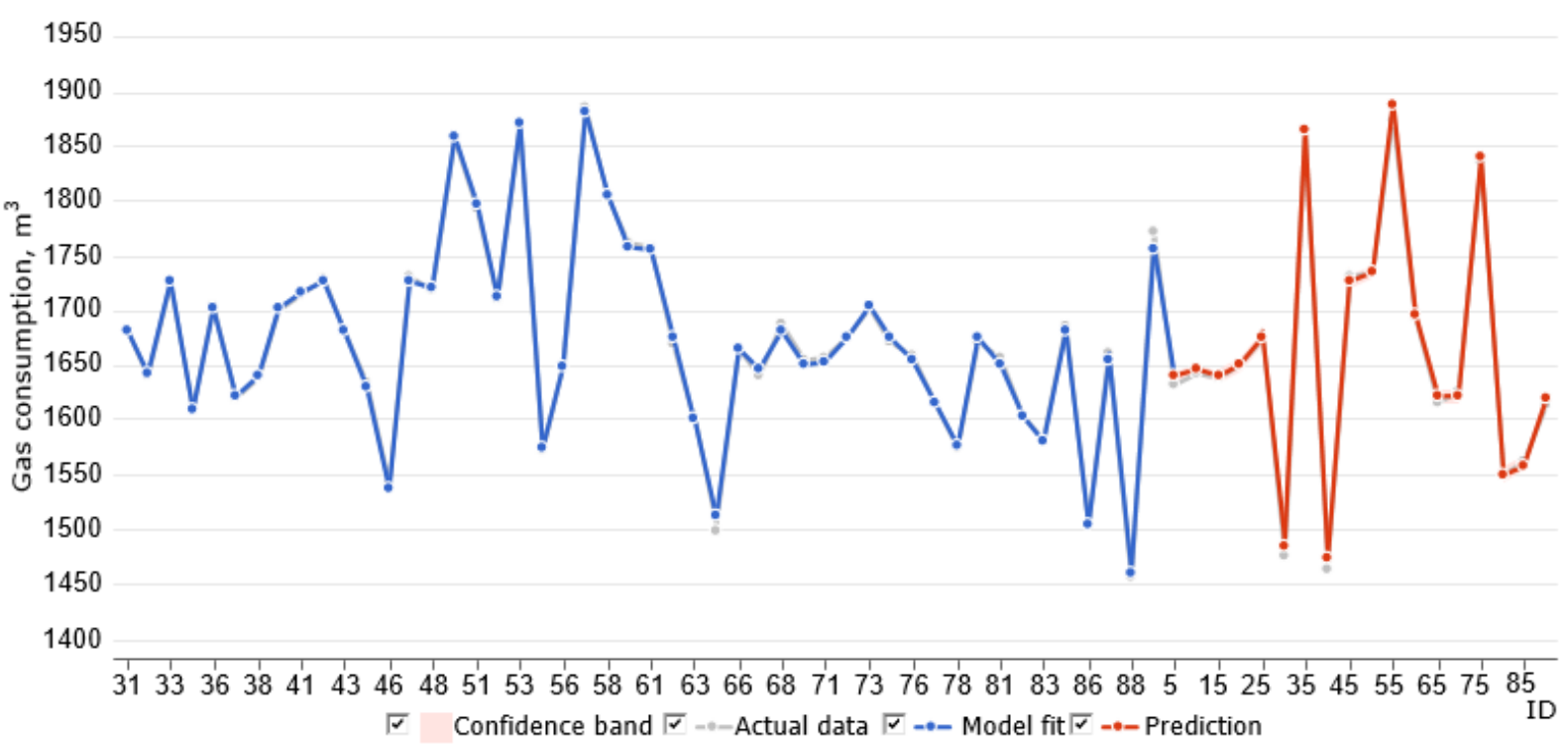

Fig. 5. Fragment of results of gas consumption simulation. 


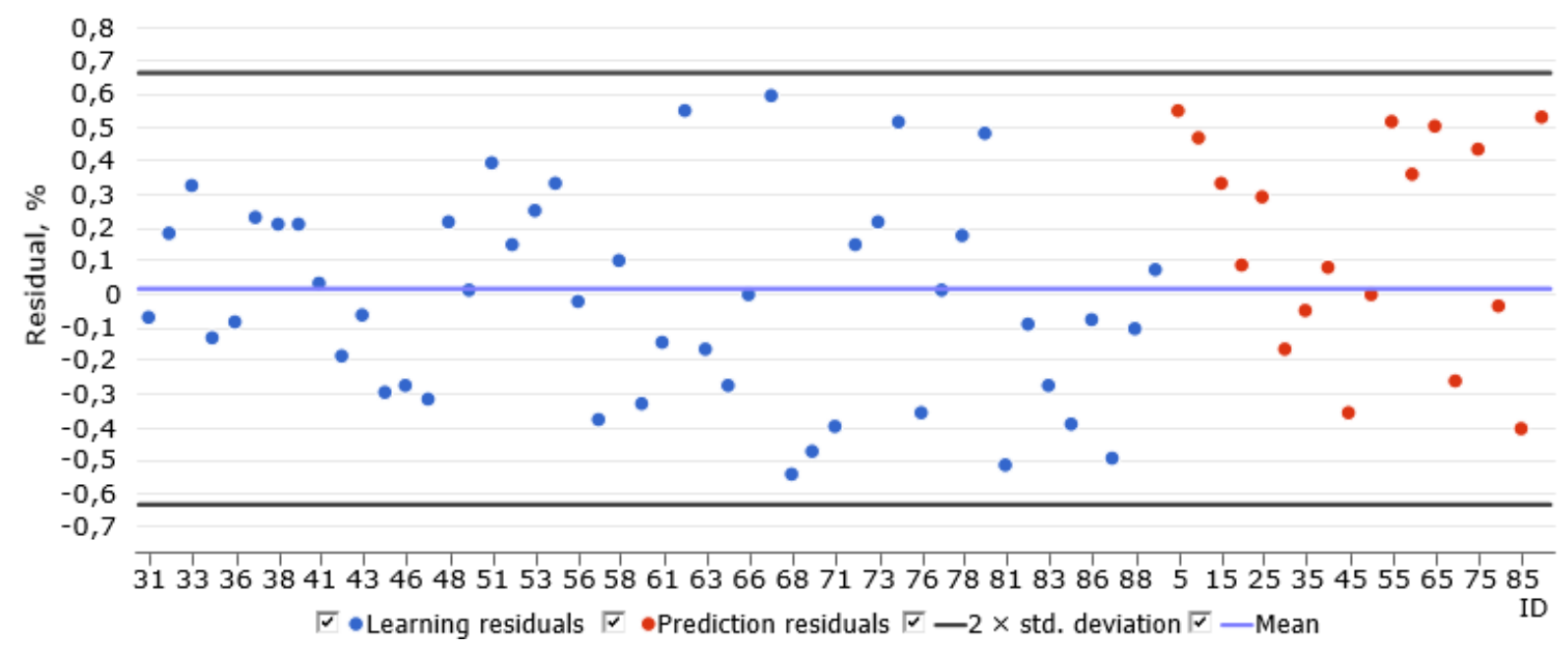

Fig. 6. Fragment of deviations of modeled and actual values of gas consumption.

Table 6.

Fragment of results of gas consumption simulation.

\begin{tabular}{|c|c|c|c|c|c|c|c|c|c|c|c|}
\hline ID, days & 86 & 87 & 88 & 89 & 5 & 10 & 15 & 20 & 25 & 30 & 35 \\
\hline${\text { Actual, } \mathrm{m}^{3}}^{1231,9}$ & 2000 & 1638,5 & 1648 & 1649 & 1659 & 1680 & 1488 & 1865 & 1438 & 1725,4 \\
\hline Forecast, $\mathrm{m}^{3}$ & 1232,9 & 2009,7 & 1640,3 & 1646,6 & 1640,3 & 1650,8 & 1674,9 & 1486,3 & 1864,6 & 1440,7 & 1726,4 \\
\hline $\begin{array}{c}\text { The lower limit } \\
\text { of the forecast }\end{array}$ & 1226,6 & 2003,4 & 1634,0 & 1640,3 & 1633,9 & 1644,5 & 1668,5 & 1479,9 & 1858,2 & 1434,4 & 1720,1 \\
\hline $\begin{array}{c}\text { The upper limit } \\
\text { of the forecast }\end{array}$ & 1239,2 & 2016,0 & 1646,7 & 1652,9 & 1646,6 & 1657,1 & 1681,2 & 1492,6 & 1870,8 & 1447,1 & 1732,7 \\
\hline Deviation, $\mathrm{m}^{3}$ & $-1,00$ & $-9,67$ & $-1,83$ & 1,37 & 8,72 & 8,19 & 5,13 & 1,19 & 0,52 & $-2,72$ & $-0,97$ \\
\hline Deviation, \% & $-0,08$ & $-0,48$ & $-0,11$ & 0,08 & 0,53 & 0,49 & 0,31 & 0,08 & 0,03 & $-0,19$ & $-0,06$ \\
\hline
\end{tabular}

The obtained results indicate that the selected model is adequate and has a low forecast error not exceeding $1 \%$.

\section{CONCLUSIONS}

The energy consumption at the CTS depends on many factors. Forming the set of relevant variables is a complex task and requires taking into consideration the experience of experts and analysis of the interconnections between the variables. The methodology for forming the set of relevant variables that have a significant influence on the energy consumption efficiency is proposed in this research. It involves the sequential application of the method of multicriteria consistent classification, the Delphi method and correlation analysis. The formation of an ordered set of informative variables is the result of applying the method of multicriteria consistent classification. This gives an opportunity to avoid differences of experts' opinions on the expediency of considering the influence of a certain variable on the solution of the set issue. The application of the Delphi method involves checking the consistency of experts' opinions and the significance of differences in selected variables. Correlation analysis provides the checking of the closeness of the connection between energy consumption and relevant variables. The application of the proposed methodology for the formation of a set of relevant variables of an EnB gives an opportunity to take into consideration not only the significance of influence of the variable on energy consumption efficiency, but also the opportunity of measurement and control the variable for the detection of causes of discrepancy between actual values of energy consumption and an EnB. The proposed methodology can be applied to form a set of significant variables that have an influence on the solution of a certain issue, taking into consideration its formulation.

The physical description of all the interconnections that determine the efficiency of energy consumption of the CTS is complicated. Therefore, the determination of EnB should implement based on data accumulated in the operation mode monitoring system of the research object, as well as take into account the real conditions of its operating and the impact of weather factors on energy consumption. 
The use of the GMDH combinatorial algorithm allowed to perform automatic structuralparametric identification of the model on the basis of experimental data in conditions when the nature of the relationship between variables is unknown, and to form a set of candidate models. All models-candidates are optimal in their class and provide a minimum of selection criteria. Herewith, the complication of the model and the increase of the polynomial degree does not significantly improve the simulation quality and forecast accuracy. Therefore, the selection of a better structure of model was proposed to perform from the standpoint of multicriteria selection, which is based on the application of criteria for simulation quality, forecast accuracy and model complexity. It is proposed to use the morphological criterion for this purpose. Its application provides the choice of a model from a set of candidate models in the case when the analysis of a set of criteria does not give an unambiguous answer, which of its structures is the best. This allowed choosing the best model structure.

As a result of application of the proposed methodology for determining the energy baseline the multifactor mathematical model of gas consumption of a boiler house was obtained. Analysis of the simulation results of the gas consumption of the boiler house showed that the percent forecasting error did not exceed 1\%. Therefore, the constructed mathematical model has a low forecast error. The application of the constructed mathematical model is the basis for determining the EnB taking into consideration the planned values of the relevant variables for further control of the efficiency of gas consumption at the boiler house. Control of the relevant variables will allow identifying the causes of discrepancy between actual value of gas consumption and an EnB. It will allow identifying the ways to reduce gas consumption.

The proposed methodology of the formation of the set of relevant variables and construction of an EnB can be applied to any facility on which the organization of control of energy consumption efficiency is provided.

\section{REFERENCES}

[1] IEA. Energy Policies Beyond IEA Countries: Ukraine 2012. Paris: OECD/IEA, 2012.

[2] Directive 2012/27/EU of the European Parliament and of the Council of 25 October 2012 on energy efficiency, amending Directives 2009/125/EC and 2010/30/EU and repealing Di- rectives 2004/8/EC and 2006/32/EC. Official Journal of the European Union, 2012, L 315, pp. 1-56. Available at: http://data.europa.eu/eli/ dir /2012/27/oj (accessed on 15.08.2021).

[3] Directive (EU) 2018/2002 of the European Parliament and of the Council of 11 December 2018 amending Directive 2012/27/EU on energy efficiency. Official Journal of the European Union, 2018, L 328, pp. 210-231. Available at: http://data.europa.eu/eli/dir/2018/2002/oj (accessed on 15.08.2021).

[4] Regulation (EU) 2018/1999 of the European Parliament and of the Council of 11 December 2018 on the Governance of the Energy Union and Climate Action, amending Regulations (EC) No 663/2009 and (EC) No 715/2009 of the European Parliament and of the Council, Directives 94/22/EC, 98/70/EC, 2009/31/EC, 2009/73/EC, 2010/31/EU, 2012/27/EU and 2013/30/EU of the European Parliament and of the Council, Council Directives 2009/119/EC and (EU) 2015/652 and repealing Regulation (EU) No $525 / 2013$ of the European Parliament and of the Council. Official Journal of the European Union, 2018, L. 328, pp. 1-77. Available at: http://data.europa.eu/eli/reg/2018/1999/oj (accessed on 15.08.2021).

[5] Vigants G., Galindoms G., Veidenbergs I. , Vigants E., Blumberga D. Efficiency diagram for district heating system with gas condensing unit. Energy Procedia, 2015, vol. 72, pp. 119126. doi:10.1016/j.egypro.2015.06.017.

[6] Prodanuks T., Vitolins V., Veidenbergs I., Blumberga D. Comparison of theoretical and practical energy efficiency values in indirect contact gas condensing unit. Energy Procedia, 2017, Vol. 128, pp. 520-524. doi:10.1016/j.egypro.2017.09.072.

[7] Ostrowski P., Szelejewski F., Zymelka P. Assessment of improvement in the energy and exergy efficiency of the gas heat plant after the exhaust gas cooled down below the dew point and the use of recovered heat. Energy, 2020, no. 190, pp. 116-179. doi:10.1016/j.energy.2019.116179.

[8] Ziemele J., Blumberga D., Talcis N., Laicane I. Industrial Research of Condensing Unit for Natural Gas Boiler House. Environmental and Climate Technologies, 2013, Vol.10 (Iss.2012), pp. 34-38. doi:10.2478/v10145-012-0023-9

[9] Thuan Le Quang S. B., Holub O., Endel P. Realtime monitoring energy efficiency and performance degradation of condensing boilers. Energy Conversion and Management, 2017, Vol. 136, p. 329-339. doi:10.1016/j.enconman.2017.01.016.

[10] Satyavada H., Baldi S. Monitoring energy efficiency of condensing boilers via hybrid firstprinciple modelling and estimation. Energy, 2018, Vol. 142, pp. 121-129. doi:10.1016/j.energy.2017.09.124. 
[11] Rämä M., Sipilä K. Transition to low temperature distribution in existing systems. Energy Procedia, 2017, Vol. 116, pp. 58-68. doi:10.1016/j.egypro.2017.05.055.

[12] Suvorov D.M., Tatarinova N.V., Lyskova E.A. The Effectiveness of Extended Schedules of Heating Regulation at CHP Plants with Decreasing Normative Design Temperature of the Supply Water. Problemele energeticii regionale, 2021, no. 4 (52), pp.99-114. doi:0.52254/18570070.2021.4-52.10.

[13] Averfalk H., Werner S. Essential improvements in future district heating systems. Energy Procedia, 2017, Vol. 116, pp. 217-225, doi:10.1016/j.egypro.2017.05.069.

[14] Pakare I., Gravelsins A., Lauka D., Blumberga D. Estimating energy efficiency increase in national district heating network. Energy Reports, 2021, Vol. 7(4), pp. 401-409. doi:10.1016/j.egyr.2021.08.088.

[15] Guelpa E., Deputato S., Verda V. Thermal request optimization in district heating networks using a clustering approach. Applied Energy, 2018, vol. 228, pp. 608-617. https://doi.org/10.1016/j.apenergy.2018.06.041.

[16] Verda V., Capone M., Guelpa E. Optimal operation of district heating networks through demand response. International Journal of Thermodynamics. 2019, Vol. 22 (No. 1), pp. 35-43. doi:10.5541/ijot.519101.

[17] Hammer A., Sejkora C., Kienberger T. Increasing district heating networks efficiency by means of temperature-flexible operation. Sustainable Energy, Grids and Networks, 2018, Vol. 16, pp. 393-404. doi:10.1016/j.segan.2018.11.001

[18] Kuosa M., Kiviranta P., Sarvelainen H., Tuliniemi E., Korpela T., Tallinen K., Koponen H.-K. Optimisation of district heating production by utilising the storage capacity of a district heating network on the basis of weather forecasts. Results in Engineering, 2022, Vol. 13, 100318, doi:10.1016/j.rineng.2021.100318.

[19] ISO 50001:2018 Energy management systems Requirements with guidance for use, ISO, 2018.

[20] ISO 50006:2014 Energy management systems measuring energy performance using energy baselines $(\mathrm{EnB})$ and energy performance indicators (EnPI) - general principles and guidance. ISO, 2014.

[21] ISO 50004:2020 Energy management systems Guidance for the implementation, maintenance and improvement of an ISO 50001 energy management system. ISO, 2020.

[22] Castrillón-Mendoza R., Rey-Hernández J. M., Rey-Martínez F. J. Industrial Decarbonization by a New Energy-Baseline Methodology. Case Study. Sustainability, 2020, vol. 12(5), pp. 19601979. doi:10.3390/su12051960.

[23] Yao D., Zhang X., Wang K., Zou T., Wang D.,
Qian X. An Energy Efficiency Evaluation Method Based on Energy Baseline for Chemical Industry. Mathematical Problems in Engineering, 2016, vol. 2016, 7087393. doi:10.1155/2016/7087393.

[24] Chen C.-W., Li C.-C., Lin C.-Y. Combine Clustering and Machine Learning for Enhancing the Efficiency of Energy Baseline of Chiller System. Energies. 2020, vol. 13(17), 4368. doi:10.3390/en13174368.

[25] Adnan W. N. W. M., Dahlan N. Y., Musirin I. Modeling baseline electrical energy use of chiller system by artificial neural network. 2016 IEEE International Conference on Power and Energy (PECon), 2016, pp. 500-505. doi: 10.1109/PECON.2016.7951613.

[26] Rossi F., Velázquez D., Monedero I., Biscarri F. Artificial neural networks and physical modeling for determination of baseline consumption of CHP plants. Expert Systems with Applications, 2014, vol. 41(10), pp. 4658-4669. doi:10.1016/j.eswa.2014.02.001.

[27] Sunthornnapha T. Utilization of MLP and Linear Regression Methods to Build a Reliable Energy Baseline for Self-benchmarking Evaluation. Energy Procedia, 2017, Vol. 141, pp. 189-193. doi.org/10.1016/j.egypro.2017.11.036.

[28] Petković D., Protić M., Shamshirband S., Akib S., Raos M., Marković D. Evaluation of the most influential parameters of heat load in district heating systems. Energy and Buildings, 2015, Vol. 104, pp. 264-274. doi:10.1016/j.enbuild.2015.06.074.

[29] Maljkovic D., Dalbelo Bašić B. Determination of influential parameters for heat consumption in district heating systems using machine learning. Energy, 2020, vol. 201, 117585, doi:10.1016/j.energy.2020.117585.

[30] Liu Y., Hu X., Luo X., Zhou Y., Wang D., Farah S. Identifying the most significant input parameters for predicting district heating load using an association rule algorithm. Journal of Cleaner Production, 2020, Vol. 275, 122984. doi:10.1016/j.jclepro.2020.122984.

[31] Arregi B., Garay R. Regression analysis of the energy consumption of tertiary buildings. Energy Procedia. 2017, Vol. 122, pp. 9-14, doi:10.1016/j.egypro.2017.07.290.

[32] Amiri S.S.; Mottahedi M.; Asadi S. Using multiple regression analysis to develop energy consumption indicators for commercial buildings in the U.S. Energy and Buildings. 2015, Vol. 109, pp. 209-216, doi:10.1016/j.enbuild.2015.09.073.

[33] Ocampo Batlle E. A., Escobar Palacio J. C., Silva Lora E. E., Martínez Reyes A. M., Balbis Morejón M. A methodology to estimate baseline energy use and quantify savings in electrical energy consumption in higher education institution buildings: Case study, UNIFEI. Journal of Cleaner Production. 2020, vol. 244, pp. 118551. 
doi:10.1016/j.jclepro.2019.118551.

[34] Jesper M., Pag F., Vajen K., Jordan U. Annual Industrial and Commercial Heat Load Profiles: Modeling Based on k-Means Clustering and Regression Analysis. Energy Conversion and Management: X, 2021, Vol. 10, 100085. doi:10.1016/j.ecmx.2021.100085.

[35] Ilbeigi M., Ghomeishi M., Dehghanbanadaki A. Prediction and optimization of energy consumption in an office building using artificial neural network and a genetic algorithm. Sustainable Cities and Society. 2020, Vol. 61, 102325. https://doi.org/10.1016/j.scs.2020.102325

[36] Mustapa R. F., Dahlan N. Y., Mohd Yassin A.I., Mohd Nordin A. H. Quantification of energy savings from an awareness program using NARX-ANN in an educational building. Energy and Buildings. 2020, Vol. 215, 109899. doi:10.1016/j.enbuild.2020.109899

[37] Fayaz M., Shah H., Aseere A. M., Mashwani W. K., Shah A. S. A Framework for Prediction of Household Energy Consumption Using Feed Forward Back Propagation Neural Network. Technologies. 2019, Vol. 7(2), 30. doi:10.3390/technologies7020030.

[38] Kim M. K., Kim Y.-S., Srebric J. Predictions of electricity consumption in a campus building using occupant rates and weather elements with sensitivity analysis: Artificial neural network vs. linear regression. Sustainable Cities and Society. 2020, Vol. 62, 102385. doi:10.1016/j.scs.2020.102385

[39] Papageorgiou K., Papageorgiou E. I., Poczeta K., Bochtis D., Stamoulis G. Forecasting of Day-Ahead Natural Gas Consumption Demand in Greece Using Adaptive Neuro-Fuzzy Inference System. Energies. 2020, Vol. 13(9), 2317. doi:10.3390/en13092317.

[40] Naji S., Shamshirband S., Basser H., Keivani A.,

\section{Information about authors.}

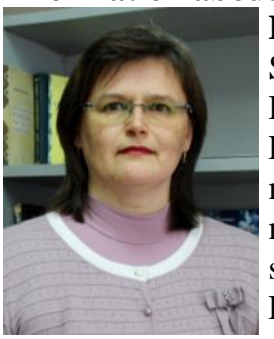

Liudmyla Davydenko, Doctor of Science (Engineering), Professor, Department of Electrical Engineering, LNTU. Scientific interests: energy management; energy efficiency monitoring of complex technological systems; energy saving.

E-mail: 1.davydenko033@gmail.com

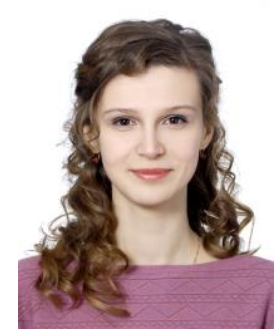

Nina Davydenko, Doctor of Philosophy (Engineering), Senior Lecturer, Department of Computer Science, LNTU. Scientific interests: energy management; energy efficiency monitoring of complex technological systems; energy saving. E-mail: ninadavydenko1992@gmail.com
Alengaram U. J., Jumaat M. Z., Petković D. Application of adaptive neuro-fuzzy methodology for estimating building energy consumption. Renewable and Sustainable Energy Reviews. 2016, Vol. 53, pp. 1520-1528. doi:10.1016/j.rser.2015.09.062

[41] Zekić-Sušac M., Mitrović S., Has A. Machine learning based system for managing energy efficiency of public sector as an approach towards smart cities. International Journal of Information Management, 2021, Vol. 58, 102074. doi:10.1016/j.ijinfomgt.2020.102074.

[42] Linstone H.A., Turoff M. The Delphi Method: Techniques and Applications. Reading, Mass.: Addison-Wesley Publishing Company, 1975.

[43] Roizenzon H.V. Ways of reduction of the dimension of the factor space for describing complex systems in decision-making issues. Artificial Intelligence News, 2005, vol. 1, pp. 18-28.

[44] Petrovskyi A.B., Roizenzon H.V. An interactive procedure for reducing the dimension of the factor space in issues of multicriteria classification. Proceedings of the ISA RAS, 2008, vol. 35, pp. 43-53.

[45] Madala H.R., Ivakhnenko O.G. Inductive Learning Algorithms for Complex Systems Modeling. Boca Raton: CRC Press, 1994.

[46] Anastasakis L., Mort N. The development of self-organization techniques in modelling: A review of the Group Method of Data Handling (GMDH). The University of Sheffield, United Kingdom, Research Report, 2001, No. 813. Available at: https://gmdhsoftware.com/ GMDH_\%20Anastasakis_and_Mort_2001.pdf. (accessed on 10.08.2021).

[47] GMDH Shell for Data Science: GMDH Shell documentation. New York: GMDH LLC, 2017. Available at: https://gmdhsoftware.com/ (accessed on 04.08.2021).

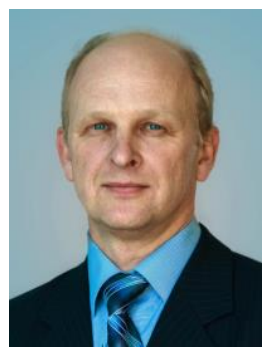

Volodymyr Davydenko Doctor of Philosophy (Engineering), Associate Professor, Department of Electrical Engineering, LNTU. Scientific interests: energy management; energy efficiency monitoring of complex technological systems. E-mail: vd19688691@gmail.com David Sprake, Senior Lecturer in Mechanical Engineering, Wrexham Glyndwr University. Scientific interests: energy modelling of smart grids; energy reduction techniques; powering future housing estates with carbon neutrality. E-mail: d.sprake@glyndwr.ac.uk 